\title{
EfFect of AnNual, BienNial, AND TrienNial In-Row Subsoiling ON SoIl COMPACTION AND COTTON Yield in Southeastern U.S. Silt Loam Soils
}

\author{
R. L. Raper, E. B. Schwab, K. S. Balkcom, C. H. Burmester, D. W. Reeves
}

\begin{abstract}
For those soils that require deep tillage to alleviate soil compaction, subsoiling can be an expensive and time-consuming tillage event. Alternative tillage methods are needed which conserve natural resources without sacrificing cotton yields. An experiment was conducted in the Tennessee Valley region of north Alabama to determine how frequently deep tillage is needed to alleviate soil compaction problems in these soils. Three different subsoilers (an in-row subsoiler and two bentleg subsoilers) were tested against a no-till treatment to determine if differences in crop productivity or soil condition could be detected. Annual subsoiling resulted in reduced bulk density compared to biennial subsoiling, triennial subsoiling, or no subsoiling. Reductions in draft force were also found for annual subsoiling. However, cotton yield results over a two-year period from tillage three-years previous, two-years previous, and one year previous found no differences.
\end{abstract}

Keywords. Soil compaction, Subsoiling, Bulk density, Cotton yield, Cone index, Draft force.

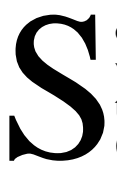

oil compaction restricts root growth throughout the world (Soane and van Ouwerkerk, 1994), and is particularly acute in many Southeastern U.S. soils (Campbell et al., 1974). During moisture-limited summer months when cash crops are actively growing, many roots cannot reach adequate soil moisture to maintain high productivity due to compacted soil layers. These compacted soil conditions are largely due to the degraded nature of these soils because they have been heavily eroded. Intensive erosion has often occurred in the Southeastern United States due to typical intensive rainfall events during times of the year when the soil surface was left unprotected.

One of the most common methods used to remove compacted soil conditions is subsoiling (Saveson and Lund, 1958; Box and Langdale, 1984; Busscher et al., 1986; Mullins et al., 1992; Vepraskas et al., 1995). This operation has frequently been conducted in the spring of the year prior to planting or in the fall of year when time was available. Most producers have conducted this tillage operation annually. Some research has indicated that it could be conducted biennially (Clark et al., 1994; Tupper et al., 1989), but the risk

Article was submitted for review in September 2004; approved for publication by the Power \& Machinery Division of ASAE in January 2005. Presented at the 2004 ASAE Annual Meeting as Paper No. 041083.

The use of trade names or company names does not imply endorsement by USDA-ARS.

The authors are Randy L. Raper, ASAE Member Engineer, Agricultural Engineer, Lead Scientist, Eric B. Schwab, Agronomist, Kipling S. Balkcom, Research Agronomist, USDA-ARS National Soil Dynamics Laboratory, Auburn, Alabama; Charles H. Burmester, Extension Agronomist, Tennessee Valley Research and Extension Center, Belle Mina, Alabama; and D. Wayne Reeves, Research Leader, USDA-ARS - J. Phil Campbell Sr. - Natural Resource Conservation Center, Watkinsville, Georgia. Corresponding author: Randy L. Raper, USDA-ARS National Soil Dynamics Laboratory, 411 S. Donahue Dr., Auburn, AL 36832; phone: 334-844-4654; fax: 334-887-8597; e-mail: rlraper@ars.usda.gov. of not subsoiling and then having a year with an extensive drought has been great enough to convince most producers to revert to the annual practice.

Research conducted in the cotton-producing Tennessee Valley region of north Alabama concluded that in-row subsoiling in the fall of the year was a positive practice when combined with the use of cover crops (Raper et al., 2000a, 2000b). Maximum cotton yields were produced with this combined practice over a 4-year period when compared to other practices. Another aspect of this study determined that the depth of in-row subsoiling needed to be targeted to the depth of soil compaction. Subsoiling deeper than the compacted depth reduced yields due to excessive soil disturbance. The experimental implement used for in-row subsoiling was manufactured by Yetter (Colchester, Ill.) with row cleaners to manage the large amounts of crop residue typically present in the field after a winter cover crop was grown. A similar study conducted in this same region found that using a Paratill ${ }^{\mathrm{TM}}$ (Bigham Brothers; Lubbock, Tex.), another form of in-row subsoling, in a conservation tillage system also reduced soil compaction and increased cotton yields (Schwab et al., 2002).

Benefits to the soil and the crop have resulted from in-row subsoiling in the Tennessee Valley region of north Alabama. However, the frequency necessary for disrupting these compacted soil profiles is not known. The current study was conceived to determine the frequency necessary for alleviation of soil compaction. Three commercially available implements were investigated to determine which of them combined with a winter cover crop would produce maximum yields. Another aspect of the study was to determine if a particular in-row subsoiler design would decrease the frequency of in-row subsoiling operations.

Therefore, the objectives of this experiment were:

- to compare the resulting soil strength for no-till and annual, biennial, and triennial subsoiling and for three selected implements, 
- to compare required draft forces for annual, biennial, triennial subsoiling and for three selected implements, and

- to compare cotton yields for no-till and annual, biennial, triennial subsoiling and for three selected implements.

\section{Methods ANd Materials}

A field was selected at the Alabama Agricultural Experiment Station's Tennessee Valley Research and Extension Center in Belle Mina, Alabama, which contained a Dewey silt loam (clayey, kaolinitic, thermic Typic Paleudult). This field had been in conventional cotton production for many years previous to this study.

This study was designed to compare the benefits of three deep tillage implements including a Kelly Manufacturing Company (KMC; Tifton, Ga.) in-row subsoiler, a Bigham Brothers Paratill $^{\mathrm{TM}}$, a Bigham Brothers Terratill ${ }^{\mathrm{TM}}$ (fig. 1), versus a no-till treatment. Shanks on all implements were 25-mm wide. The KMC shank had an angle of $45^{\circ}$ and used replaceable wear tips (44-mm width). Wear plates were used with the shanks to simulate conditions of actual use. The Paratill $^{\mathrm{TM}}$ shank is bent to one side by $45^{\circ}$, with the leading edge rotated forward by $25^{\circ}$, and has a $57-\mathrm{mm}$ wide point. As the shank is traveling forward, it contacts the soil over a 216-mm width. The Terratill ${ }^{\mathrm{TM}}$ is a slightly narrower version of the Paratill ${ }^{\text {TM }}$ but has a 76-mm wide point. As this shank is traveling forward, it contacts the soil over a narrower width of $127 \mathrm{~mm}$. Two of the implements were selected (KMC in-row subsoiler and the Bigham Brothers Paratill ${ }^{\mathrm{TM}}$ ) because they were commonly being used by producers in this region to reduce soil compaction. The Bigham Brothers Terratill ${ }^{\mathrm{TM}}$ was selected because it was being marketed as an alternative to the Paratill ${ }^{\mathrm{TM}}$ with a smaller draft requirement and reduced soil disruption. Each of these implements consisted of a 4-row system with four shanks preceded by a coulter.

The experimental design was a randomized complete block with a $3 \times 3$ factorial arrangement of treatments augmented with an additional control treatment of no-tillage with a cover crop. The two factors were: 1) subsoiler implement (KMC in-row subsoiler, Paratill ${ }^{\mathrm{TM}}$, and Terratill $^{\mathrm{TM}}$ ), and 2) subsoiler application (annual, biennial, and triennial). Each treatment was replicated four times. The experiment was set up in a staggered form with the first set of subsoil treatments conducted in the fall of 1999 (table 1). Annual subsoil treatments were conducted with each implement that would allow complete results to be obtained for annual subsoiling, biennial subsoiling, and triennial subsoiling in years 2002 and 2003. Two years of complete yield data allowed reasonable comparisons to be made for all subsoiling treatments and to determine if reconsolidation occurred for these soils once they were disturbed and managed by conservation tillage systems. All treatments included the use of a rye (Secale cereale L.) winter cover crop because previous experiments had found benefits associated with its use (Raper et al., 2000b; Schwab et al., 2002).

The plots were four 1.02-m (40-in.) rows wide by $53.3 \mathrm{~m}$ (175 ft.) long. The substantial length of these plots was selected to attempt to consider the natural variability in soil strength that may occur over a farm. The center two rows were harvested and a weighing boll buggy was used to obtain cotton yield.

A Trimble AgGPS Autopilot steering system (Overland Park, Kans.) was used on a John Deere 8300 tractor (Moline, Ill.) to facilitate placement of plant rows and subsoiling in the same location within the plots for all years. In conjunction with a Real-Time Kinematic (RTK) Global Positioning System (GPS), this steering system was able to maintain straight lines across the field with accuracies of 2 to $3 \mathrm{~cm}$ (1 in.). The use of this system was important to maintain location across these large plots because the subsoiling operation was conducted in the fall of the year followed by the cover crop, which grew to heights greater than $1 \mathrm{~m}$ (40 in.). During planting operations the following spring, it was difficult to visually determine where the previous fall's subsoiling operations had been conducted. The automatic steering system allowed rows to be placed adjacent to the subsoiling locations.

To determine the depth of tillage necessary to disrupt compacted soil profiles, multiple cone-index measurements were obtained in this field. These measurements showed that the depth of the compacted soil layer occurred at a $0.30-\mathrm{m}$ (12-in) depth. Therefore, the depth of tillage was set at $0.33 \mathrm{~m}$ (13 in.).

The implements were mounted on a three-dimensional dynamometer supplied by the USDA-ARS National Soil Dynamics Research Laboratory in Auburn, Alabama during the last two years of the experiment. This device measured draft, vertical, and side forces required for tillage for each plot. A radar gun was used to obtain tillage speed which was used along with the mean draft data to obtain subsoiling energy necessary for tillage. These measurements enabled comparison between the three implements as well as the different periods of reconsolidation resulting from the previous tillage.

Soil strength and soil moisture measurements were taken in fall 2003. Soil strength was determined by using a tractor-mounted multiple-probe soil cone penetrometer (MPSCP; Raper et al., 1999) and then calculating the cone
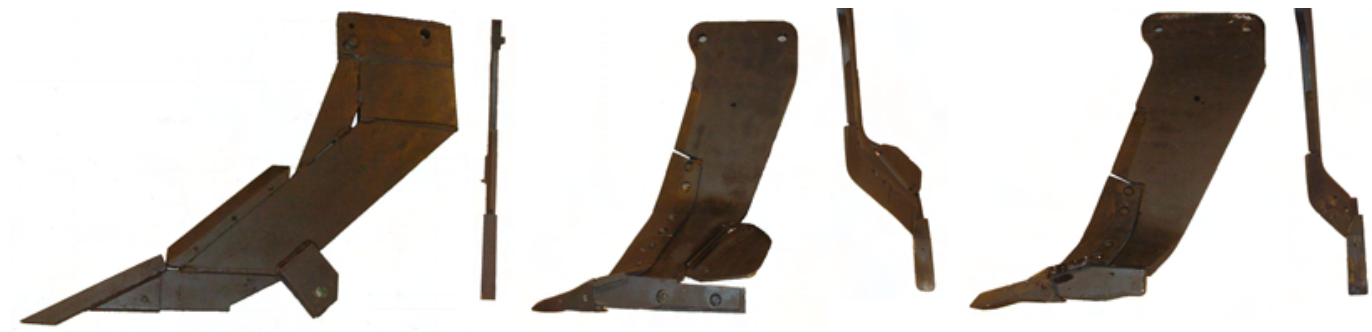

Figure 1. Side and front views of KMC subsoiler (left), Paratill ${ }^{\mathrm{m}}$ (center), and Terratill ${ }^{\mathrm{TM}}$ (right) used in the experiment. 
Table 1. Experiment layout of subsoiling treatments.

\begin{tabular}{|c|c|c|c|c|c|}
\hline \multirow[b]{2}{*}{ Year } & \multirow[b]{2}{*}{ Annual } & \multicolumn{2}{|c|}{ Biennial } & \multicolumn{2}{|c|}{ Triennial } \\
\hline & & Plot Set 1 & Plot Set 2 & Plot Set 1 & Plot Set 2 \\
\hline 1999 & Subsoiled & Subsoiled & & Subsoiled & \\
\hline 2000 & $\begin{array}{r}\text { Harvested \& } \\
\text { subsoiled }\end{array}$ & & Subsoiled & & Subsoiled \\
\hline 2001 & $\begin{array}{r}\text { Harvested \& } \\
\text { subsoiled }\end{array}$ & $\begin{array}{r}\text { Harvested \& } \\
\text { subsoiled }\end{array}$ & & & \\
\hline 2002 & $\begin{array}{r}\text { Harvested \& } \\
\text { subsoiled }\end{array}$ & & Harvested & Harvested & \\
\hline 2003 & Harvested & Harvested & & & Harvested \\
\hline
\end{tabular}

index (ASAE Standards, 1999a, 1999b). Five penetrometer probes were inserted: (a) in the row, (b) midway between the row and the untrafficked row middle $[25 \mathrm{~cm}$ (10 in) from the row], (c) in the untrafficked row middle [51 cm (20 in.) from the row], (d) midway between the row and the trafficked row middle [ $25 \mathrm{~cm}$ (10 in.) from the row], and (e) in the trafficked row middle [51 cm (20 in) from the row]. For this study, only positions a, c, and e were analyzed. Three insertions per plot were obtained. The MPSCP was also fitted with a core sampler to obtain measurements of bulk density at depths of 0 to $5 \mathrm{~cm}$ (0 to $2 \mathrm{in}$.), 10 to $15 \mathrm{~cm}$ (4 to 6 in.), 20 to $25 \mathrm{~cm}$ ( 8 to 10 in.), 25 to $30 \mathrm{~cm}$ (10 to 12 in.), and 30 to $35 \mathrm{~cm}$ (12 to $14 \mathrm{in}$.) in the row following harvest of the 2003 crop. Particular attention was focused on obtaining bulk density data near the bottom of the subsoiled zone to evaluate reconsolidation. Three sets of bulk density measurements were obtained per plot.

The factorial arrangement of 10 treatments, including the no-till treatment, within the randomized complete block was analyzed with an appropriate ANOVA model using SAS (Cary, N.C.). Treatment effects were separated using nine single degree of freedom contrasts (table 2). A predetermined significance level of $\mathrm{P} \leq 0.1$ was chosen to separate treatment effects.

\section{Results AND Discussion}

\section{SoIL MoISTURE}

Soil moisture was relatively constant with depth at the time of sampling and only ranged from 0.20 to 0.22 (table 3 ).
Table 2. Single-degree-of-freedom-contrasts used to assist with data analysis.

Single Degree of Freedom Contrasts

Soil contrasts

Annual subsoiling vs. no-till

Annual subsoiling vs. biennial subsoiling

Annual subsoiling vs. triennial subsoiling

Biennial subsoiling vs. triennial subsoiling

No-till vs. biennial subsoiling

No-till vs. triennial subsoiling

Implement contrasts

Terratill $^{\mathrm{TM}}$ vs. KMC

KMC vs. Paratill ${ }^{\mathrm{TM}}$

Paratill $^{\mathrm{TM}}$ vs. Terratill ${ }^{\mathrm{TM}}$

Table 3. Gravimetric moisture content across all treatments

obtained at time of cone index and bulk density sampling.

\begin{tabular}{lc}
\hline Depth $(\mathrm{cm})$ & Moisture Content $(\%)$ \\
\hline $0-5$ & $0.22(0.12)^{[\mathrm{a}]}$ \\
$10-15$ & $0.20(0.01)$ \\
$20-25$ & $0.20(0.01)$ \\
$25-30$ & $0.21(0.02)$ \\
$35-40$ & $0.22(0.02)$ \\
\hline
\end{tabular}

[a] Numbers in parentheses indicate standard deviation.

\section{SoIL Bulk Density \\ Longevity Effects}

Annual subsoiling reduced bulk density values at the shallow depth of 0 to $5 \mathrm{~cm}$ ( 0 to 2 in.) compared to biennial subsoiling $(\mathrm{P} \leq 0.005)$, triennial subsoiling $(\mathrm{P} \leq 0.032)$, and no-till ( $\mathrm{P} \leq 0.022)$ (fig. $2 \mathrm{~A})$. At the 10 - to $15-\mathrm{cm}(4-$ to 6 -in.) depth, annual subsoiling reduced bulk density compared to triennial subsoiling $(\mathrm{P} \leq 0.035)$ and no-till $(\mathrm{P} \leq 0.006)$. Biennial subsoiling also reduced bulk density compared to no-till ( $\mathrm{P} \leq 0.030)$. At the 20 - to $25-\mathrm{cm}(8$ - to 10 -in.) depth, annual subsoiling reduced bulk density compared to biennial subsoiling $(\mathrm{P} \leq 0.051)$, triennial subsoiling $(\mathrm{P} \leq 0.001)$, and no-till ( $\mathrm{P} \leq 0.001)$. Biennial subsoiling also reduced bulk density compared to no-till ( $\mathrm{P} \leq 0.022)$. At the 25 - to $30-\mathrm{cm}$ (10- to 12-in.) depth, annual subsoiling reduced bulk density compared to biennial subsoiling $(\mathrm{P} \leq 0.012)$, triennial subsoiling ( $\mathrm{P} \leq 0.026)$, and no-till $(\mathrm{P} \leq 0.008)$. At the 35 - to
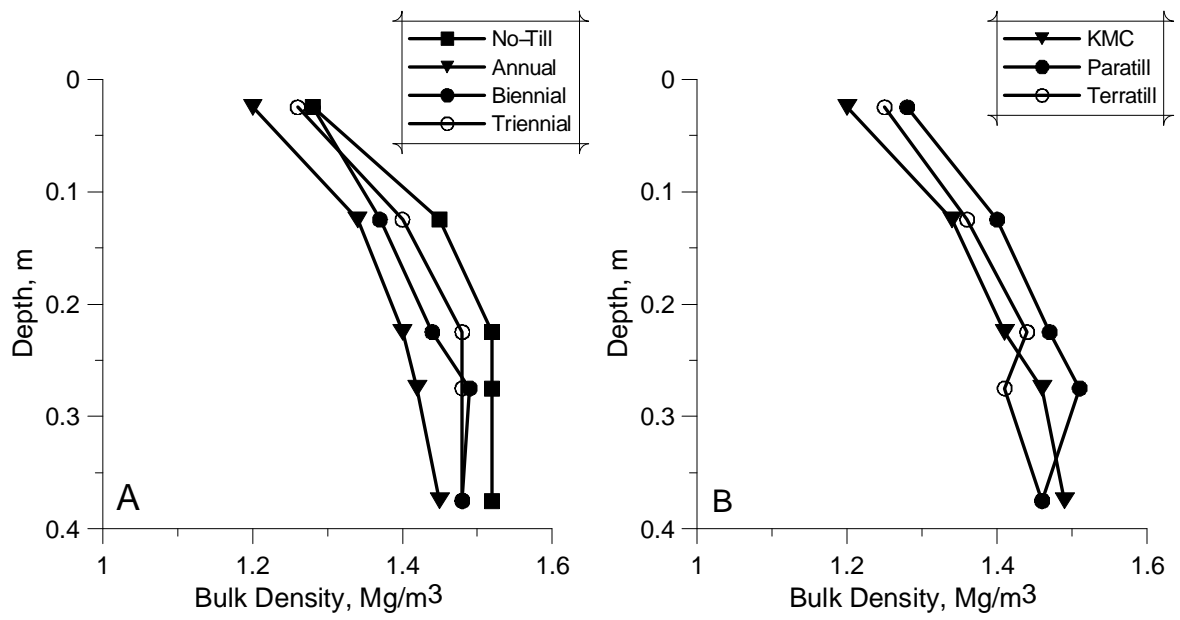

Figure 2. In-row bulk density values averaged across implements (A) and averaged across years since subsoiling (B). 
40-cm (12- to 14-in.) depth, annual subsoiling only reduced bulk density compared to no-till $(\mathrm{P} \leq 0.050)$.

\section{Implement Effects}

No difference in bulk density was found between implements at the shallow depth of 0 - to 5 -cm (0- to 2-in.) (fig. 2B). At the 10- to 15-cm (4- to 6-in.) depth, reduced bulk density was found with the KMC subsoiler compared to the Paratill ${ }^{\mathrm{TM}}$ $(\mathrm{P}=0.033)$. At the 20- to $25-\mathrm{cm}$ (8- to 10-in.) depth, the KMC subsoiler was again found to reduce bulk density compared to the Paratill ${ }^{\mathrm{TM}}(\mathrm{P} \leq 0.051)$. At the $25-$ to $30-\mathrm{cm}(10-$ to 12-in.) depth, minimum bulk density resulted from using the Terratill $^{\mathrm{TM}}$, which was significantly less than bulk densities resulting from the Paratill ${ }^{\mathrm{TM}}(\mathrm{P} \leq 0.003)$, or the $\mathrm{KMC}$ subsoiler $(\mathrm{P} \leq 0.030)$. The KMC also reduced bulk density compared to the Paratill ${ }^{\text {TM }}(\mathrm{P} \leq 0.067)$. No differences due to implements were found at the deepest depth sampled [35 to $40 \mathrm{~cm}$ (12 to 14 in)].

\section{Longevity-Implement Interactions}

Reconsolidation of soil disturbed by subsoiling began immediately after tillage and continued for up to 3 years, where triennial subsoiling and no-till treatments resulted in similar values of bulk density. With the exception of one treatment, the minimum bulk density at all depths was caused by annual subsoiling using any of the three implements (fig. 3) and the maximum bulk density was caused by the no-till treatment. The exception was the triennial subsoiling treatment using the Paratill ${ }^{\mathrm{TM}}$ where at a depth of 0 to $5 \mathrm{~cm}$ (0 to 2 in.), bulk density was smaller than all treatments, and depths of 10 to $15 \mathrm{~cm}$ (4 to 6 in.), 20 to $25 \mathrm{~cm}$ (8 to 10 in.), and 25 to $30 \mathrm{~cm}$ (10 to 12 in.) where bulk density was greater than the no-till treatment. This tillage treatment seemed to allow the soil to reconsolidate at a faster rate at most depths.

The KMC implement resulted in a gradual reduction in bulk density at all depths (fig. 4). Near the surface, all tilled soils reconsolidated to bulk densities similar to the no-till treatment. However, the KMC implement tended to maintain the loosest soil profile for the longest period of time. The Paratill ${ }^{\mathrm{TM}}$ treated soils consolidated within the 3-year period to bulk densities similar to no-till. Reeves et al. (1992) reported that a completely disrupted soil profile resulted in the highest levels of bulk density when traffic occurred. Creating a wide zone of loosened soil may have actually increased compaction as forces from vehicle tires propagated downward and recompacted soil. A narrower zone of loosened soil such as provided by the KMC subsoiler may have offered roots a downward path to grow while limiting reconsolidation from vehicle traffic.

\section{SoIL CONE INDEX}

Cone index values obtained at three positions across the row were examined for differences in soil strength as a result of subsoiling (fig. 5). All three figures showed the effects of traffic and subsoiling on cone index. Values obtained in the trafficked row middle (fig. 5, right) were much greater than those measured in any other row position and commonly exceeded $2 \mathrm{MPa}$ (particularly near the soil surface) which is sometimes considered the maximum value of cone index for optimum cotton root growth (Taylor and Gardner, 1963). Cone index values in the row (fig. 5, center) were reduced
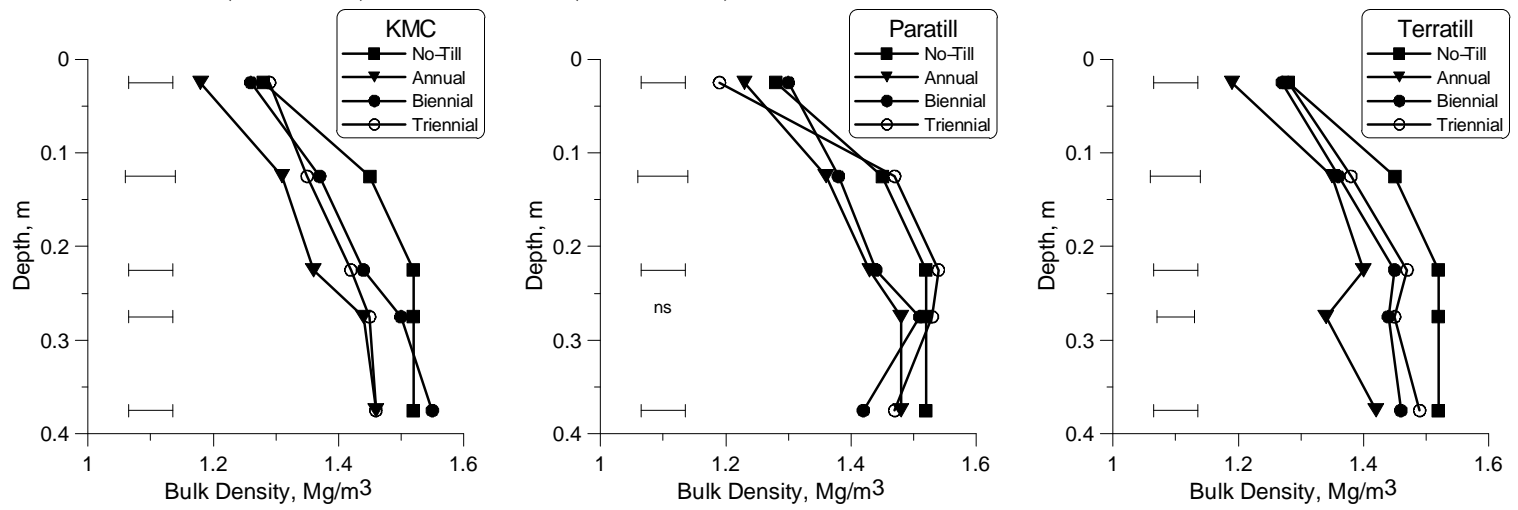

Figure 3. In-row bulk density values for each implement. Length of error bars indicates $\operatorname{LSD}_{(0.1)}$.
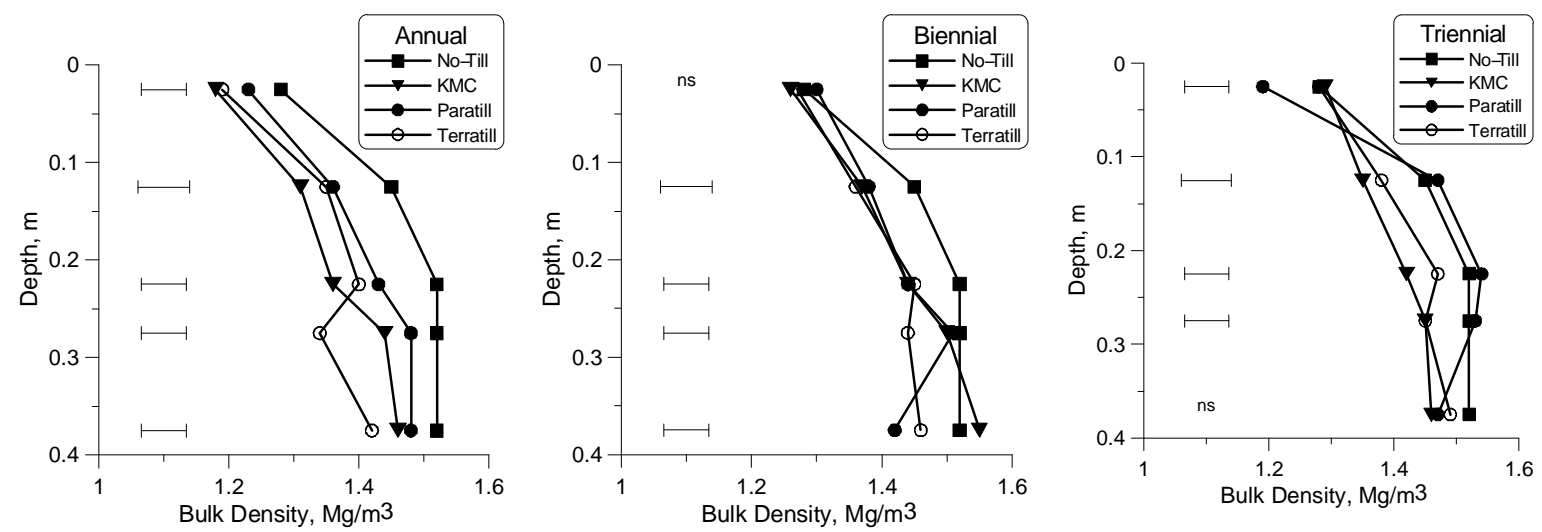

Figure 4. In-row bulk density values for each subsoiling frequency. Length of error bars indicates $\operatorname{LSD}_{(0.1)}$. 

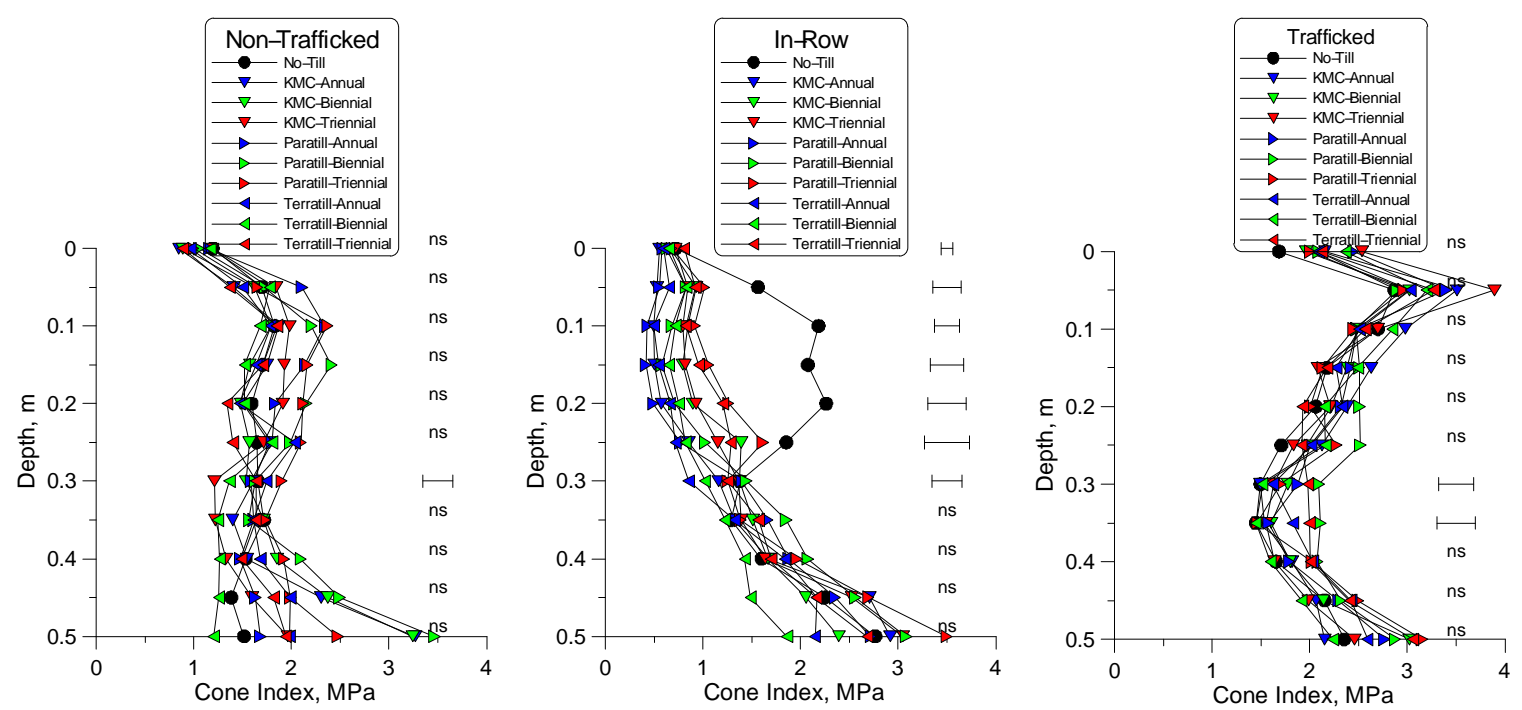

Figure 5. Cone index values obtained for each tillage treatment in different row positions. Length of error bars indicates $\operatorname{LSD}_{(0.1)}$.

from the other two positions and show the benefits offered by subsoiling, especially when compared to the no-till treatment. Also, the annual subsoiling treatments have minimum values of cone index as compared to biennial and triennial subsoiling treatments (fig. 5, center).

\section{Draft ForCe}

Because of the unique layout of the experiment, two consecutive years of data were obtained to compare subsoiling force across all subsoiling treatments (fig. 6). In 2002, gravimetric soil moisture at the time of subsoiling was found to be $17.5 \%$ at the 0 - to $15-\mathrm{cm}(0-$ to 6 -in.) depth and $18.5 \%$ at the $15-$ to $30-\mathrm{cm}$ (6- to 12-in.) depth. In 2002, annual subsoiling reduced draft force $(34.1 \mathrm{kN})$ compared to biennial subsoiling $(38.1 \mathrm{kN} ; \mathrm{P}=0.001)$ or triennial subsoiling (39.0 kN; $\mathrm{P} \leq 0.001)$. The $\mathrm{KMC}$ implement had reduced draft force $(27.1 \mathrm{kN})$ compared to the Terratill ${ }^{\mathrm{TM}}$ $(45.7 \mathrm{kN} ; \mathrm{P} \leq 0.001)$ or the Paratill ${ }^{\mathrm{TM}}(38.3 \mathrm{kN} ; \mathrm{P} \leq 0.001)$. The Paratill ${ }^{\mathrm{TM}}$ also had reduced draft forces compared to the Terratill $^{\mathrm{TM}}(\mathrm{P} \leq 0.001)$.

In 2003, gravimetric soil moisture at the time of subsoiling was found to be $17.8 \%$ at the 0 - to $15-\mathrm{cm}$ (0- to 6-in.) depth and $18.3 \%$ at the $15-$ to $30-\mathrm{cm}$ (6- to 12-in.) depth. In 2003, no differences in draft forces were found between implements. However, annual subsoiling $(22.6 \mathrm{kN})$ reduced draft forces compared to biennial subsoiling $(24.9 \mathrm{kN} ; \mathrm{P}=0.002)$ and triennial subsoiling (26.9 $\mathrm{kN} ; \mathrm{P} \leq 0.001)$. Biennial subsoiling was also found to differ significantly from triennial subsoiling $(\mathrm{P} \leq 0.007)$.

In 2002, draft force increased substantially as the subsoiling frequency decreased (fig. 6). This trend was not clearly seen in 2003. Similar soil moisture values were measured in both years, so the difference in draft forces is not easily understood or explained.

\section{COTTON YIELD}

Despite improved soil conditions caused by the subsoiling treatments, cotton yield did not improve substantially due to subsoiling. During all years of the experiment, few differences in seed cotton yield were found as a result of the various tillage implements or the time since their use.

In 2002, seed cotton yield showed no overall treatment effect $(\mathrm{P} \leq 0.23$; fig. 7 , top). However, using single degree of freedom contrasts and when averaged across the years since its use, the Terratill ${ }^{\mathrm{TM}}$ was found to improve yield $[2304 \mathrm{~kg} / \mathrm{ha}$ (2052 lb/acre)] compared to the KMC subsoiler [2053 kg/ha
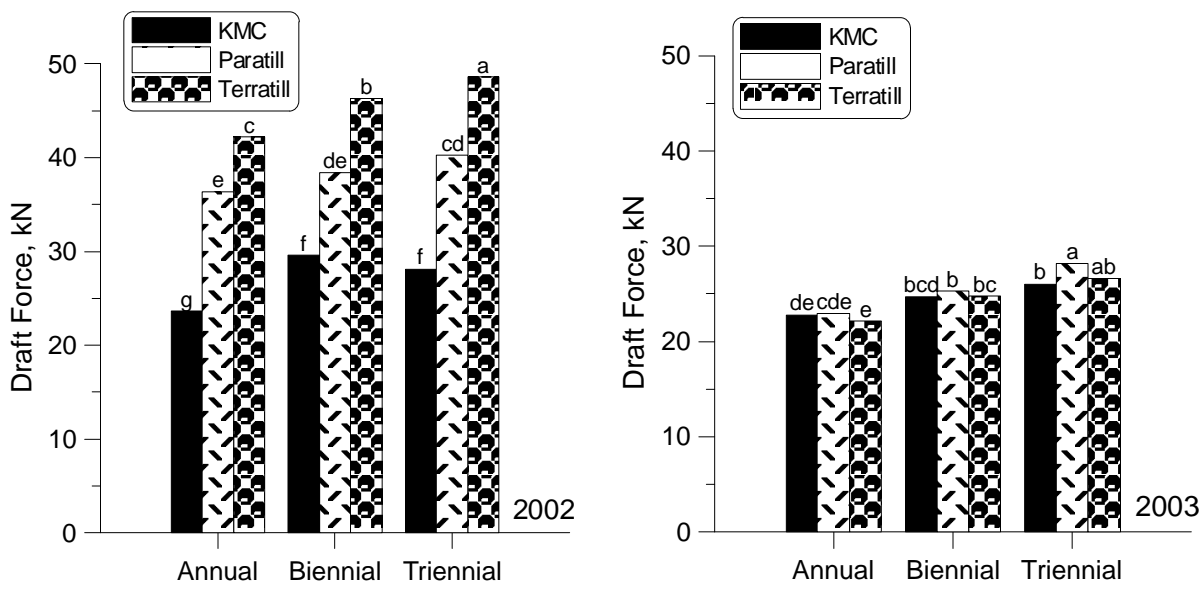

Figure 6. Draft forces for years 2002 and 2003 showing differences in subsoiling implements and subsoiling frequency. Letters were used to indicate statistical differences $\left(\mathbf{L S D}_{\mathbf{0 . 1}}\right)$. 

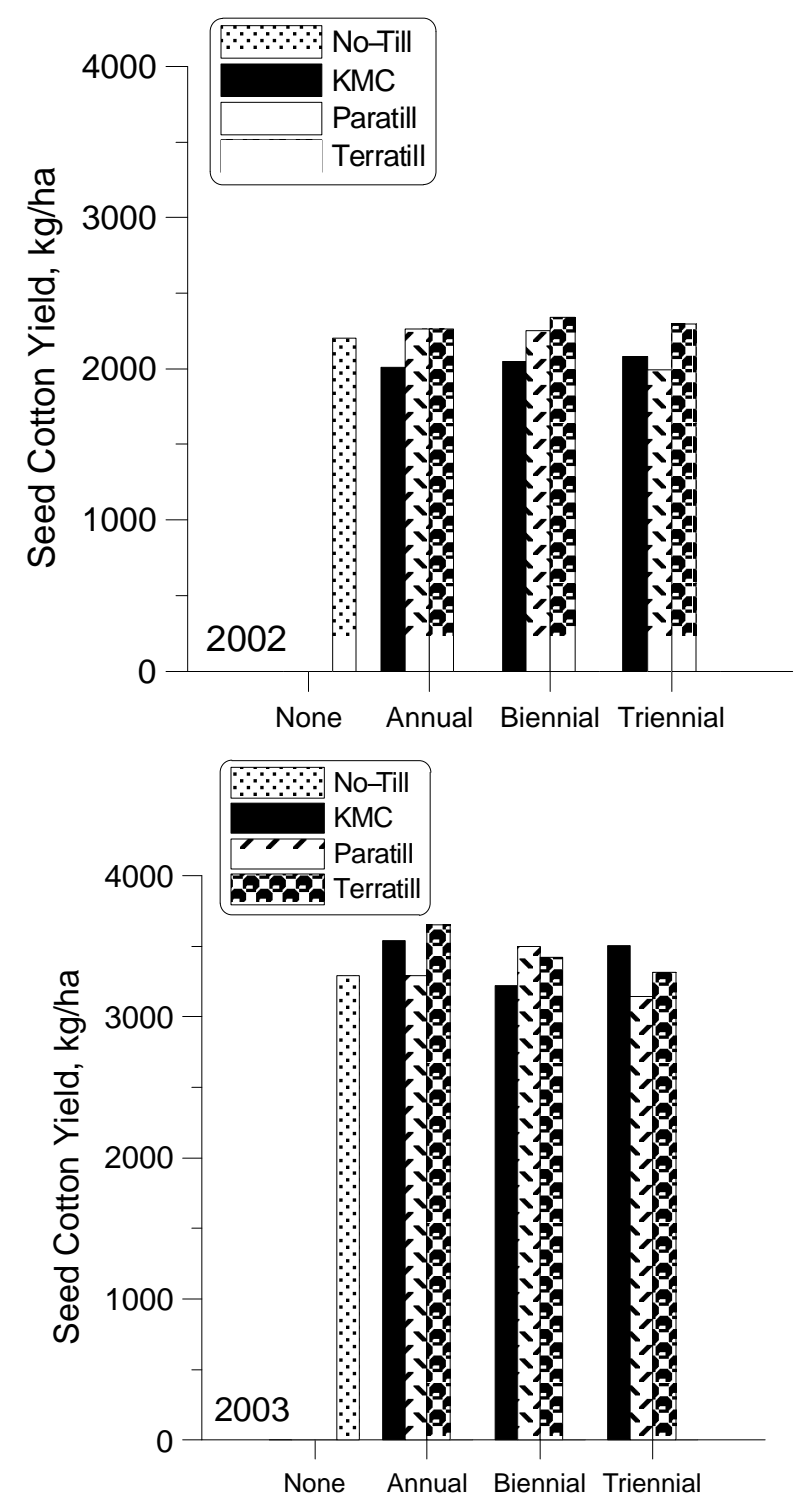

Figure 7. Cotton yields for years 2002 and 2003 showing differences in subsoiling implements and subsoiling frequency.

(1829 lb/acre); $\mathrm{P} \leq 0.01]$ and compared to the Paratill ${ }^{\mathrm{TM}}$ [2152 kg/ha (1917 lb/acre); P $\leq 0.08]$.

In 2003, similar results for yield were found with no overall treatment effect ( $\mathrm{P} \leq 0.16$; fig. 7 , bottom). However, when averaged across tillage implements and separated using single degree of freedom contrasts, annual tillage was found to result in higher yields [3495 $\mathrm{kg} / \mathrm{ha}(3113 \mathrm{lb} / \mathrm{acre})]$ as compared to tillage every 3 years $[3322 \mathrm{~kg} / \mathrm{ha}(2959 \mathrm{lb} / \mathrm{acre})$; $\mathrm{P} \leq 0.10]$.

Averaged across both years, no significant treatment effect was found ( $\mathrm{P} \leq 0.38$; data not shown). A trend was found using single degree of freedom contrasts to examine differences between annual tillage [2799 kg/ha $(2493 \mathrm{lb} /$ acre)] and tillage every 3 years [2730 kg/ha (2432 lb/acre); $\mathrm{P} \leq 0.12$ ]. However, one should take note that no differences were found in any year or in the averaged year data with respect to differences between the no-till treatment and any other tillage treatment including the various implements or the time since their use.

\section{Conclusions}

The conclusions that can be drawn from this experiment are:

- Annual subsoiling reduced bulk density values compared to biennial subsoiling, triennial subsoiling, and no-till. Reconsolidation of soil disturbed by subsoiling began immediately after tillage and continued for up to 3 years, where triennial subsoiling and no-till treatments resulted in similar soil bulk densities. The KMC implement maintained the loosest soil profile for the longest period of time and produced minimum bulk densities. The Paratill ${ }^{\mathrm{TM}}$ im- $^{\mathrm{im}}$ plement consolidated within the 3-year period to bulk densities similar to no-till. Differences in cone index were seen across the row with the loosest soil condition being directly in the center of the row where subsoiling was conducted. In this condition, all subsoiling treatments had reduced cone index compared to no-till. The greatest cone index values were obtained in the trafficked row middle near the soil surface, where all treatments had similar values.

- Minimum draft forces were obtained with the annual subsoiling treatments compared to biennial or triennial subsoiling. The KMC implement required minimum draft forces, with the Paratill ${ }^{\mathrm{TM}}$ also requiring less than the Terratill ${ }^{\mathrm{TM}}$.

- No improvements in cotton lint yield were found as a result of the use of the three tested subsoiling implements compared to strict no-tillage with a rye cover crop. No improvements in cotton lint yield were found based on timesince-use of the tillage implement. Annual subsoiling did not improve yields over subsoiling conducted 3 years previous.

\section{REFERENCES}

ASAE Standards, 45th Ed. 1999a. EP542. Procedures for obtaining and reporting data with the soil cone penetrometer. St. Joseph, Mich.: ASAE.

ASAE Standards, 45th Ed. 1999b. S313.2. Soil cone penetrometer. St. Joseph, Mich.: ASAE

Box, J., and G. W. Langdale. 1984. The effects of in-row subsoil tillage and soil water on corn yields in the Southeastern coastal plain of the United States. Soil Till. Res. 4(1): 67-78.

Busscher, W. J., R. E. Sojka, and C. W. Doty. 1986. Residual effects of tillage on Coastal Plain soil strength. Soil Sci. 141(2): 144-148.

Campbell, R. B., D. C. Reicosky, and C. W. Doty. 1974. Physical properties and tillage of Paleudults in the southeastern Coastal Plains. J. Soil Water Cons. 29(5): 220-224.

Clark, R. L., D. E. Radcliffe, G. W. Langdale, and R. R. Bruce. 1994. Soil strength and water infiltation as affected by paratillage frequency. Transactions of the ASAE 36(5): 1301-1305.

Mullins, G. L., D. W. Reeves, C. H. Burmester, and H. H. Bryant. 1992. Effect of subsoiling and the deep placement of $\mathrm{K}$ on root growth and soil water depletion by cotton. In Proc. Beltwide Cotton Production Research Conf., 1134-1138. Nashville, Tenn.: National Cotton Council.

Raper, R. L., D. W. Reeves, C. H. Burmester, and E. B. Schwab. 2000a. Tillage depth, tillage timing, and cover crop effects on cotton yield, soil strength, and tillage energy requirements. Applied Engineering in Agriculture 16(4): 379-385. 
Raper, R. L., D. W. Reeves, E. B. Schwab, and C. H. Burmester. 2000b. Reducing soil compaction of Tennessee Valley soils in conservation tillage systems. J. Cotton Sci. 4(2): 84-90.

Raper, R. L., B. H. Washington, and J. D. Jarrell. 1999. A tractor-mounted multiple-probe soil cone penetrometer. Applied Engineering in Agriculture 15(4): 287-290.

Reeves, D. W., H. H. Rogers, J. A. Droppers, S. A. Prior, and J. B. Powell. 1992. Wheel-traffic effects on corn as influenced by tillage system. Soil Till. Res. 23(1-2): 177-192.

Saveson, I. L., and Z. F. Lund. 1958. Deep tillage for crop production. Transactions of the ASAE 2(1): 40-42.

Schwab, E. B., D. W. Reeves, C. H. Burmester, and R. L. Raper. 2002. Conservation tillage systems for cotton grown on a silt loam soil in the Tennessee Valley. J. Soil Sci. 66(2): 569-577.
Soane, B. D., and C. van Ouwerkerk. 1994. Soil compaction problems in world agriculture. In Soil Compaction in Crop Production, eds. B. D. Soane, and C. van Ouwerkerk, 1-22.ed. Amsterdam: Elsevier.

Taylor, H. M., and H. R. Gardner. 1963. Penetration of cotton seedling taproots as influenced by bulk density, moisture content, and strength of soil. Soil Sci. 96(3): 153-156.

Tupper, G. R., J. G. Hamill, and H. C. Pringle, III. 1989. Cotton response to subsoiling frequency. In Proc. Beltwide Cotton Prod. Res. Conf., 10. Nashville, Tenn.: National Cotton Council. Vepraskas, M. J., W. J. Busscher, and J. H. Edwards. 1995. Residual effects of deep tillage vs. no-till on corn root growth and grain yield. J. Prod. Agric. 8(3): 401-405. 
